\title{
Electronic versus Print Journals in Academic Libraries in Abu Dhabi: Preference \& Problems
}

\author{
Khaled Ahmed Halloumeh ${ }^{1 *}$, Jassim Mohammed Jirjees ${ }^{2}$ \\ ${ }^{1}$ The Petroleum Institute Library, Abu Dhabi, UAE \\ ${ }^{2}$ MLIS Program Director, AUE, Dubai, UAE \\ Email: *khalloumeh@pi.ac.ae
}

How to cite this paper: Halloumeh, K. A., \& Jirjees, J. M. (2016). Electronic versus Print Journals in Academic Libraries in Abu Dhabi: Preference \& Problems. Advances in Journalism and Communication, 4, 113126.

http://dx.doi.org/10.4236/ajc.2016.44011

Received: September 8, 2016

Accepted: December 12, 2016

Published: December 15, 2016

Copyright $\odot 2016$ by authors and Scientific Research Publishing Inc. This work is licensed under the Creative Commons Attribution International License (CC BY 4.0). http://creativecommons.org/licenses/by/4.0/

\begin{abstract}
With the invasion of information communication technology and shortages in library budgets, there is a growing need to continuously evaluate library resources and know what library patrons prefer. This study examines electronic versus print journal preferences and problems in academic libraries in Abu Dhabi. The survey research method was used to do this study, and a questionnaire was distributed to three graduate educational institutions in Abu Dhabi Emirate, United Arab Emirates.
\end{abstract}

\section{Keywords}

Electronic Versus Print Journals, Academic Libraries, Preference, Problems

\section{Introduction}

\subsection{Background}

ICT has affected all areas of life and its use is common in libraries. In order to provide better services to patrons, consequently, most libraries have transformed into virtual libraries, which increases the global dissemination of knowledge. Juma, Wamukoya, \& Wekullo (2014) said that digital libraries had a huge potential towards offsetting the knowledge deficit in many parts of the world and Africa in particular. Their study investigated the level to which they had helped to reduce disparities in access to knowledge and promote the quality of education and research in Africa.

During the last year of undergraduate study and at the graduate level, journal articles become more understandable, more essential and more important; it is considered to be the most important source of information. In his study, Mazur (2008) found that learning journals were a viable instructional strategy for many, but not all adult learners enrolled in OL degree programs. Journaling can deepen and broaden students' under- 
standing of leadership by internalizing and integrating learning as well as providing a study tool. Learning journals generate greater self-awareness in many students through increased self-knowledge and recognition of personal strengths, feelings, and emotions. Learning journals contributed to personal and leadership growth and some found them an effective problem solving tool. Journaling encouraged students to apply learning through changed thinking and behavior.

Tenopir (2002) mentioned that in the 2002 issue of Ulrich's list of worldwide serials, there were approximately 16,000 scholarly peer-reviewed journals listed, and over 12,000 of those were available in the electronic form. According to an email from ProQuest client service specialist in the UAE (Sayed Magdy, email, 7 July 2015) in 2015, the numbers of peer-reviewed journals in Ulrich's were as follows:

"Print and online" journals: 32,805,

"Print only" journals: 20,842,

"Electronic only" journals: 11,963.

\subsection{Statement of the Problem}

Debates about library patron's format preferences have been ongoing since the mid 1980 's. It is clear that the dependence on electronic journals has become more and more necessary. In a research study done by Rupp-Serrano \& Robbins (2013) it is mentioned that participants emphasize the importance of electronic access to scholarly journals and library databases and the continuing value of books, both print and electronic, for meeting the information and research needs of education faculty.

This study compares the journal format preferences of academic libraries in Abu Dhabi for the purpose of assisting libraries in determining the journal formats most often selected by their patrons.

\subsection{Objectives of the Study}

In the process of choosing the best journal format, libraries should identify the evaluation criteria that control the process. In fact the researchers believe usage specifications are one of the most important criteria in evaluating the library journals, so the objectives of this study are the following:

1) Determining which journal format that faculty members and graduate students in Abu Dhabi academic libraries prefer to use for their studies and research.

2) Finding the problems of electronic and print journal usage.

\subsection{Significance of the Study}

In this research, faculty members and graduate students declared their journal format use preferences. The results of this research will benefit the acquisition strategies and serials collection development policies of libraries, by helping them to better serve library patrons.

\subsection{Scope of the Study}

Scope of this study is as follows: 
- Area: Abu Dhabi Emirate.

- Population: Faculty and graduate students in academic institutions in Abu Dhabi.

- Period: Year 2015

\subsection{Definitions of Terms}

Here are some definitions of some expressions which will be used in this research:

Electronic Journal: A scholarly journal that can be accessed via electronic transmission and has the purpose of providing material for academic research and study. Some electronic journals are online-only journals; others are online versions of printed journals.

Print Journal: The paper version of journal; print journal issues are the ones that we usually checked in through library integrated systems.

Library Patrons: In this paper we mean faculty members and graduate students in Abu Dhabi academic institutions.

\section{Literature Review}

After reviewing the literature of this subject, the researchers would like to discuss the related studies according to the following five headings.

\subsection{From Print to Electronic}

Angrosh (2005) mentioned that the new technologies have largely aided in designing value-added library services. The emerging digital libraries are redefining the way by which user demands are being fulfilled. Among other resources, electronic journals occupy a prominent place in digital libraries, by providing access to online full-text information.

Fortini (2007) mentioned in his paper that academic libraries are increasing the number of electronic journals in their collections. While patrons enjoy access to articles with the click of a button, librarians face the complex process of implementing and maintaining the subscriptions.

Tobia \& Hunnicutt (2008) said that electronic journals have become the preferred method for accessing the journal literature. The next logical step is for librarians to carefully evaluate traditional staff activities still focused on the maintenance of shrinking print journal collections.

In his study, McClamroch (2011) examined the factors considered by college and university libraries in Indiana when making the decision to cancel subscriptions to print journals when an electronic equivalent is available. The results show that consortium members use subscription cost, redundancy of formats, student preference, budget reduction and usage as the primary factors in cancelling print journal subscriptions in favor of their electronic counterparts. There is also a preference for the electronic format for new subscriptions even when a print version is also available.

Kumar \& Gupta (2013) mentioned that users are either preferring e-journals or are uncertain about them. Print journals still find wide applicability and this transition will 
take time to settle down.

McMullen (2014) said that the conversion of a print journal subscription to electronic access resulted in a substantial decrease in cost per use despite an increase in overall subscription cost.

\subsection{Importance of Usage/Citation Statistics}

Cooper (2007) explained that tracking the usage of print and electronic journals will help librarians understand the complexities of use studies. He examined qualitative and quantitative studies by academic librarians to compare the usage of electronic versus print journals, and the strengths and weaknesses inherent in the methods used. New initiatives, such as Project COUNTER (Counting Online Usage of Networked Electronic Resources), seek to provide librarians with comparable usage data from various vendors enable librarians to make more informed journal collection development decisions.

In their paper, Schloegl \& Gorraiz (2011) followed the transition from print journals to electronic (hybrid) journals in the preceding decade. Usage metrics became an interesting complement to citation metrics. In this article they investigate the similarities and differences between usage and citation indicators for pharmacy and pharmacology journals. They concluded that electronic journals have become generally accepted. While the supply of Science Direct pharma journals rose by 50\% between 2001 and 2006, the total number of article downloads multiplied more than 5-fold in the same period.

\subsection{Effect on Educational Process}

Aggarwal \& Bhalla (2012) mentioned that technology has influenced all the spheres of life and the field of education is not an exception. Technology has manifold advantages namely, convenience, cost effectiveness, and round the clock availability. Due to these advantages, electronic information resources are pointing towards an appealing future. The field of education has also undergone this transition. But there is an urgent need to study this transition because teacher educators are entrusted with the important responsibility of producing teachers deal effectively with the rapid advancement of technology in education.

In the findings of their paper, Stoop, Kreutzer \& Kircz (2013) showed that print-onpaper is still a superior medium for learning and digesting complicated and elaborate texts, while electronic screens are appreciated for quick information gathering, communication and navigation.

\subsection{Effect on Scholarly Communication}

Kumar \& Grover (2007) said that scholarly communication has many roles as making formal knowledge available to the public, developing new knowledge and teaching. Journals play a crucial role in scholarly communication and the scholarly publishing has made direct connection between authors and users. Some references cited in articles of 
electronic journals have hyperlinks.

In their study, Dastforoush \& Venkatesha (2011) examined the dependency on electronic and print journals of the most frequent users among scholars and faculty in Iran. A total of 118 faculty members and research scholars were selected. Questionnaires were given to the selected sample. Descriptive and inferential statistics were used. The results showed that the majority of users had high dependency on electronic journals.

\subsection{Effect on Research}

Electronic journals influence scholarship and research. While usage statistics deal only with the usage numbers, research deals with a wider picture of usage. That research shows the ratios of user preference and discusses different specifications and opinions regarding journals usage.

Sathe, Grady, \& Giuse (2002) study investigated the impact of electronic journals on research processes such as information seeking. The authors conducted a pilot journal-use study to test the hypothesis that patrons use print and electronic journals differently. The data revealed that there were distinct preferences in format among categories. In addition to collection management implications for libraries, these data also have implications for publishers and educators; current electronic formats do not facilitate all types of uses and thus may be changing learning patterns as well.

Heterick (2002) (as cited in Adegbore, 2011) reports that more than $60 \%$ of faculty studied are comfortable using electronic resources. They believe that a variety of electronic resources are important to their research. And they consider electronic databases to be invaluable. In addition, $62 \%$ expect that they will become increasingly dependent on electronic resources in the future.

\section{Methodology}

\subsection{Design of the Investigation}

The following efforts were made for achieving the goals of this study. Necessary information about the universities related to the population of the research has been collected and the survey method chosen. Then a sample was selected and a questionnaire designed in such a way to cover all the questions that this research intended to answer. The questionnaire was distributed and the data has been collected and analyzed in a professional way so that the results reflect high validity and reliability.

According to Ministry of Higher Education and Scientific Research in UAE (http://www.mohesr.gov.ae/ar/Pages/default.aspx), the number of educational establishments in Abu Dhabi is 25. Of these, 17 offer graduate studies. In order to get more information about these universities and in addition to email and phone correspondence, the researchers visited most of the seventeen graduate academic institutions. Finally, a sample of three universities was selected in this study.

The questionnaire of this study has been divided into the following parts:

Demographic Details: In this part the researchers aimed to get a general idea about the participants in the study and their background. 
Research Details: This is in order to have some information about participants' opinions regarding electronic and print journals.

An online based questionnaire, using Survey Monkey, was distributed to the three universities selected in this study.

The number of participants was 200, which was around $9 \%$ of the total number of faculty members and graduate students $(\mathrm{N}=2319)$. From a statistical point of view, the response rate was reasonably good from the three universities selected. All the data collected have been treated as per the standard structures and policies of evaluation, manipulation and analysis of information.

\subsection{The Sample}

In order to give more validity and reliability to the study, it has been limited to three academic institutions in Abu Dhabi Emirate only. Then the researchers got the sample for their study via two steps. In the first step, the two researchers took a purposive sample from above mentioned 17 educational establishments according to the two following factors:

1) Governmental or private educational establishment

2) Availability of print journals in the educational establishment

Using the first step, 4 universities have been eliminated. The second step was getting a stratified sample from the remaining 13 universities according to colleges and programs offered. Eventually, the researchers selected three universities which have different colleges offering different educational programs.

Table 1 shows the number of faculty and graduate students in the three universities which were chosen as a sample for this study:

Table 2 shows the number of electronic journals and the number of print journals in these universities:

Table 1. Faculty members and graduate student numbers in the sample universities.

\begin{tabular}{|c|c|c|}
\hline University Name & Faculty Number & $\begin{array}{c}\text { Graduate Students } \\
\text { Number }\end{array}$ \\
\hline $\begin{array}{l}\text { Al Ain University for Science and Technology } \\
\text { (http://www.aau.ac.ae) }\end{array}$ & 50 & 600 \\
\hline The Petroleum Institute (http://www.pi.ac.ae) & 228 & 342 \\
\hline Zayed University (http://www.zu.ac.ae) & 304 & 795 \\
\hline
\end{tabular}

Table 2. Electronic and print journal numbers in the sample universities.

\begin{tabular}{ccc}
\hline University Name & $\begin{array}{c}\text { Electronic Journals } \\
\text { Number }\end{array}$ & $\begin{array}{c}\text { Print Journals } \\
\text { Number }\end{array}$ \\
\hline Al Ain University for Science and Technology & 19,000 & 60 \\
The Petroleum Institute & 39,228 & 320 \\
Zayed University & 65,113 & 198 \\
\hline
\end{tabular}




\subsection{Treatment}

The questionnaire was sent to faculty members and graduate students through the Research Departments in the three above universities. Participants' responses have been organized according to themes found in the literature, and some other new themes emerge from experience with significant library topics.

\subsection{Data Analysis Procedure}

Directly after the survey was closed, the responses were downloaded into an Excel spreadsheet. Then the researchers consulted with a statistical expert. After that, the data was uploaded into SPSS version 22 for statistical analysis. The results have been arranged logically with concentration on the most significant features related the thesis subject and which answer its questions.

\section{Results \& Discussions}

\subsection{Demographic Findings}

The following figures show all the demographic findings of this research:

The number of participants has been divided among the three samples universities as follows: (Figure 1).

The number of participants has been divided among the different colleges in the above mentioned three universities as follows: (Figure 2).

The following figure (Figure 3 ) shows the distribution of participants according to their computer literacy standard.

And the following figure (Figure 4) shows the distribution of participants according to their academic status.

\subsection{Research Findings}

Upon checking the research results, it has been generally found that the highest number of respondents with the ratio $65 \%$ declared that "electronic journals have more advantages than print journals", which is actually an expected ratio in the current shift toward

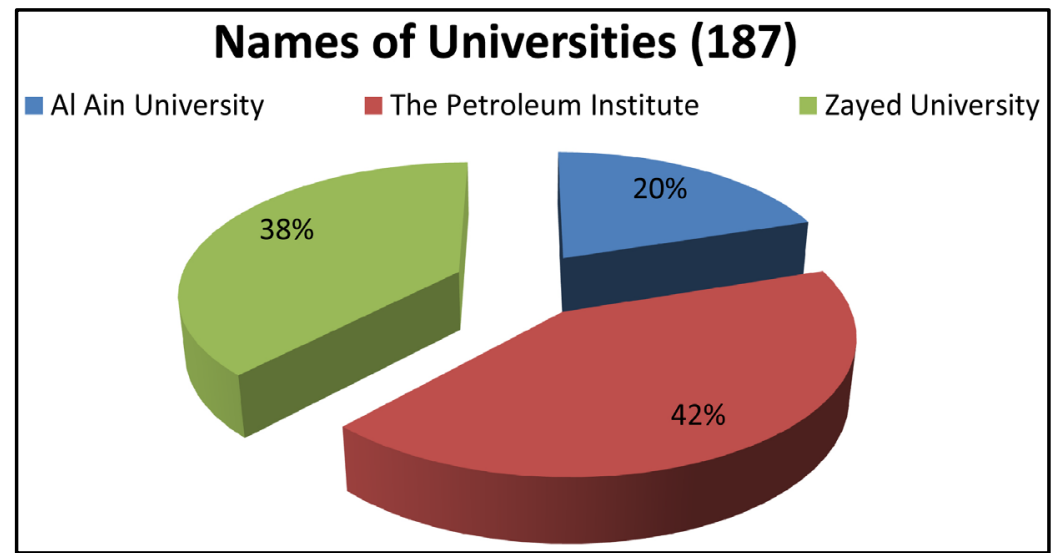

Figure 1. Names of universities. 


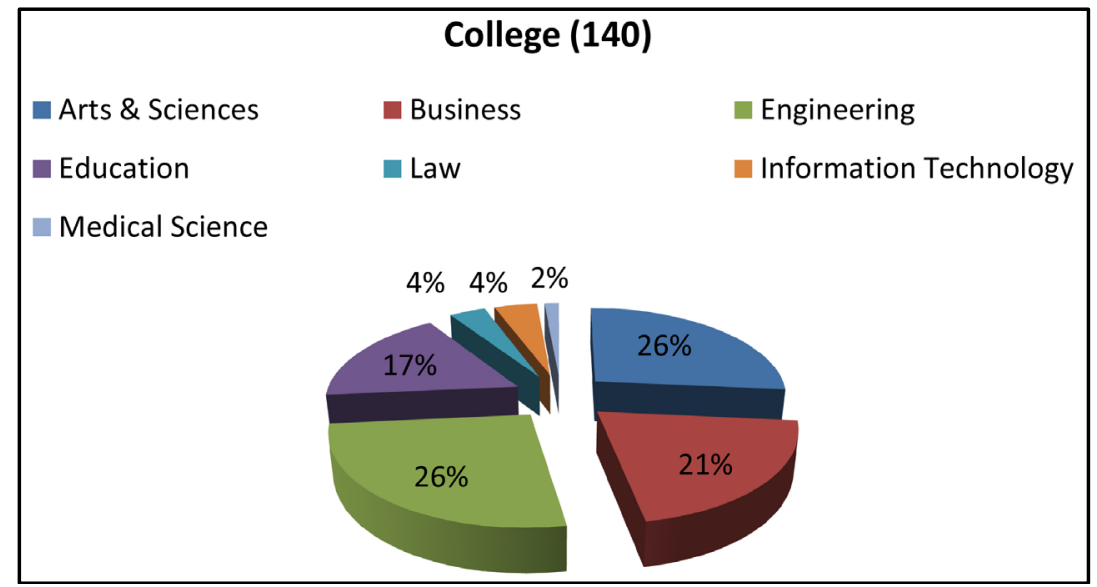

Figure 2. Colleges (disciplines).

\section{Computer Literacy (194)}

Basic Inermediate Advance

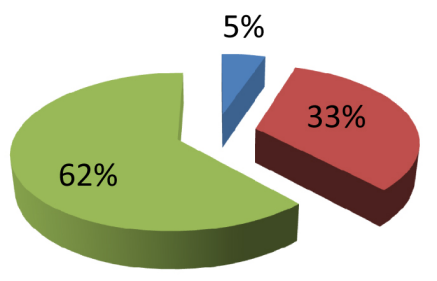

Figure 3. Computer literacy.

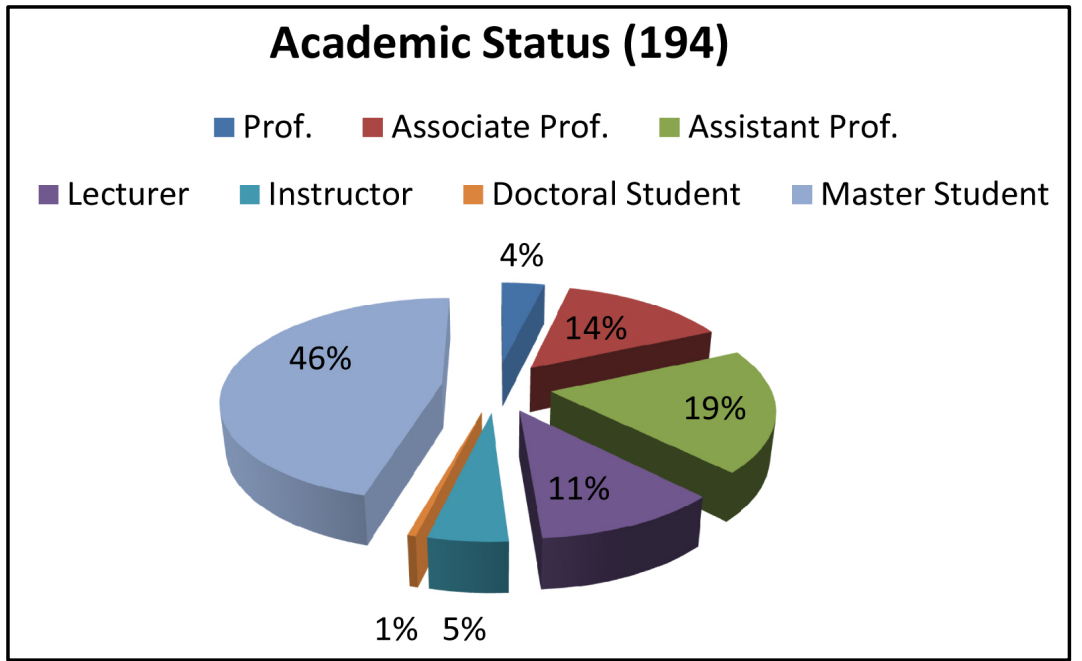

Figure 4. Academic status.

an electronic environment in libraries as elsewhere. But there is still a good ratio of respondents (22\%) who said that "electronic and print journals are equal". Also it is noticed that around $13 \%$ of respondents said that "print journals have more advantages 
than electronic journals". Figure 5 clearly shows these findings:

Recently there have been many debates in libraries to decide if print version of journals should be cancelled or not if the electronic version of the same journal is available in the library. So the following question is very important as it will give information related to this matter. Figure 6 shows that the majority of respondents (around 70\%) said that "both versions should be kept". Around one third of respondents said that "print version should be cancelled". Although these numbers show that there is a good trend toward more dependence on electronic format of journals, there is still much interest in having the print copy of journals on the library shelves in addition to the electronic version.

The clear interest in electronic journal is shown by the findings that $43 \%$ of respondents

\section{What is your opinion of the two journal formats (184)}

- Electronic journals have more advantages than print journals

Electronic and print journals are equal

Print journals have more advantages than electronic journals

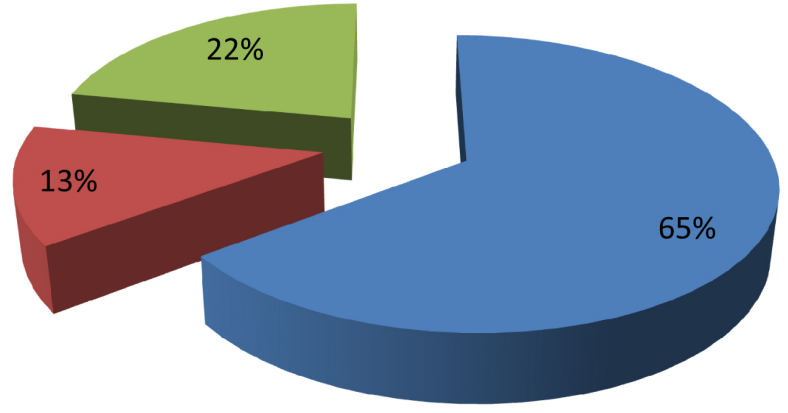

Figure 5. What is your opinion about the two journal formats?

If both formats of a journal are available in your library, then (184)

Both versions should be kept Print version should be cancelled Electronic version should be cancelled

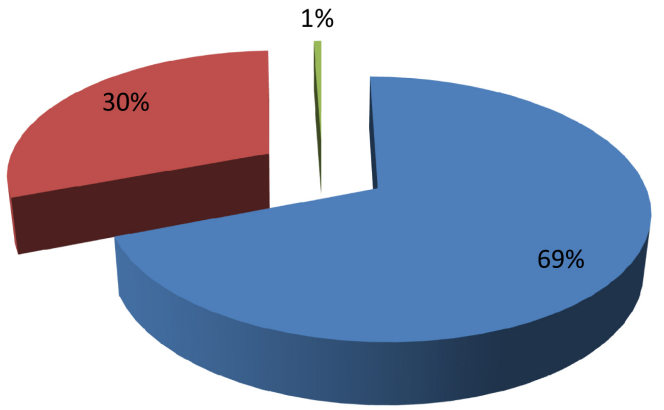

Figure 6. What is your opinion if both formats of a journal are available in your library? 
stated that they use electronic journals "several times a week", $20 \%$ use them "several times a month" and 17\% "daily". Options "once a month" and "once a week" were chosen by only $13 \%$ and $7 \%$ of participants respectively (Figure 7).

It is obvious that the types of problems which electronic journal users face are mostly related to information technology which is enhanced and upgraded continuously in order keep the prosperity of electronic journals. When participants were asked about these problems, it has been found that the major difficulty was "access problems" with ratio of $65 \%$, the second highest is for "searching problems" with a ratio of $35 \%$. There were low problem ratios for "saving/archiving", "printing" and others (Figure 8).

For print journals, low usage has been noticed, where $35 \%$ of participants use print journals "once a month", $27 \%$ of participants use them "several times a week", $22 \%$ use them "several times a month", $14 \%$ use it "once a week", and a very small ratio of participants (2\%) use print journals on daily basis while daily usage was $17 \%$ for electronic journals (Figure 9).

Despite the low usage of print journals, when participants were asked about the problems when using them, the ratios are generally low for having problems like: "physical access", "missing or damaged issues", photocopying problems, "copyright problems"

\section{How frequently do you use electronic journals? (171)}
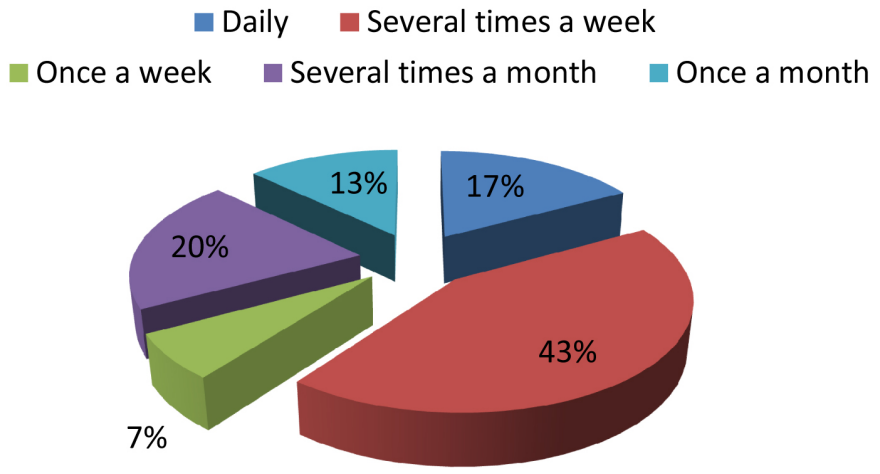

Figure 7. How frequently do you use electronic journals?

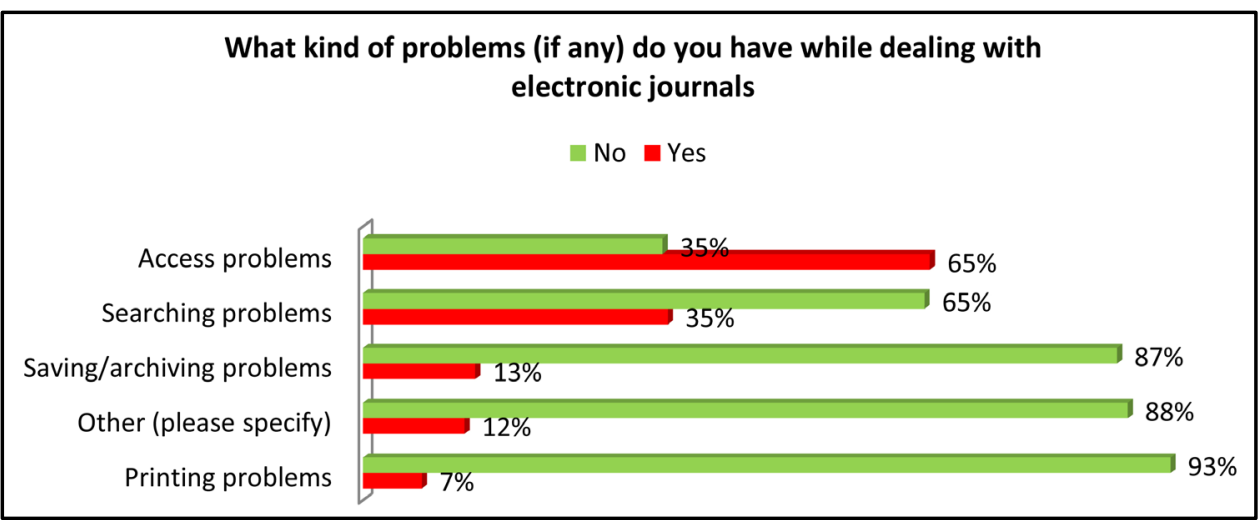

Figure 8. What kind of problems (if any) do you have while dealing with electronic journals? 
and "delayed issues" (25\%, 23\%, 22\%, 21\%, and 21\%) respectively (Figure 10). Few participants said they have searching problems for articles in the journals.

These results match the result of Profera \& Stamison (2010), which found that the demand for electronic content is rising within the information community. The growing popularity of e-resources translates to various issues facing library organizations.

\section{Conclusion \& Recommendations}

\subsection{Conclusion}

This research looked at academic libraries in Abu Dhabi Emirate in order to find out the preference of electronic versus print journals and usage problems of each journal format. Generally, the findings of the study reflected a very high preference for electronic journals over print journals by both faculty members and graduate students.

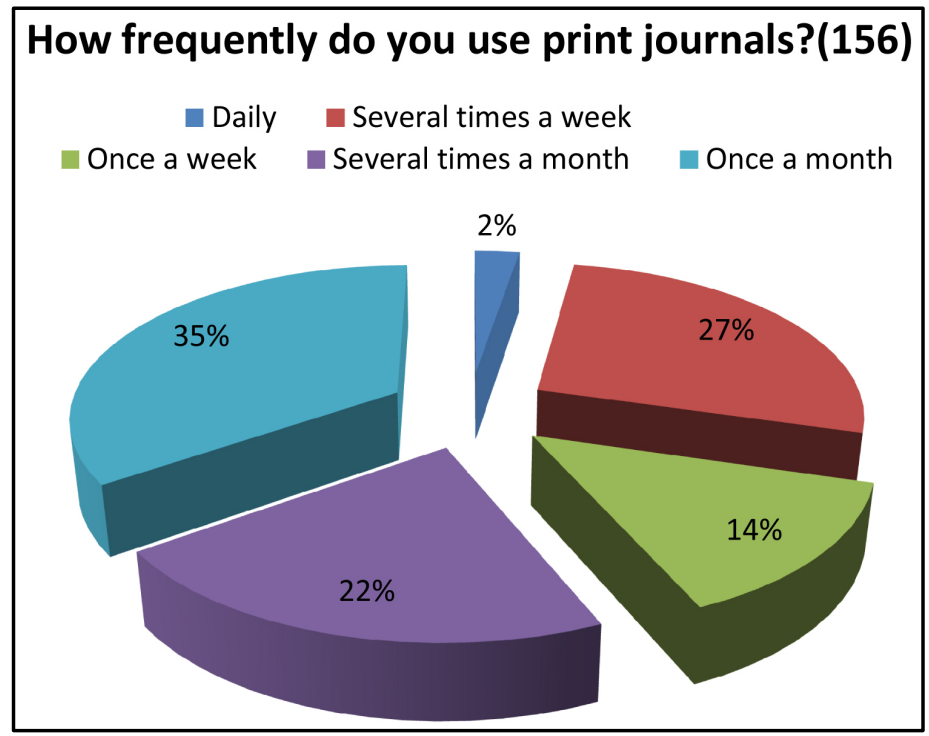

Figure 9. How frequently do you use print journals?

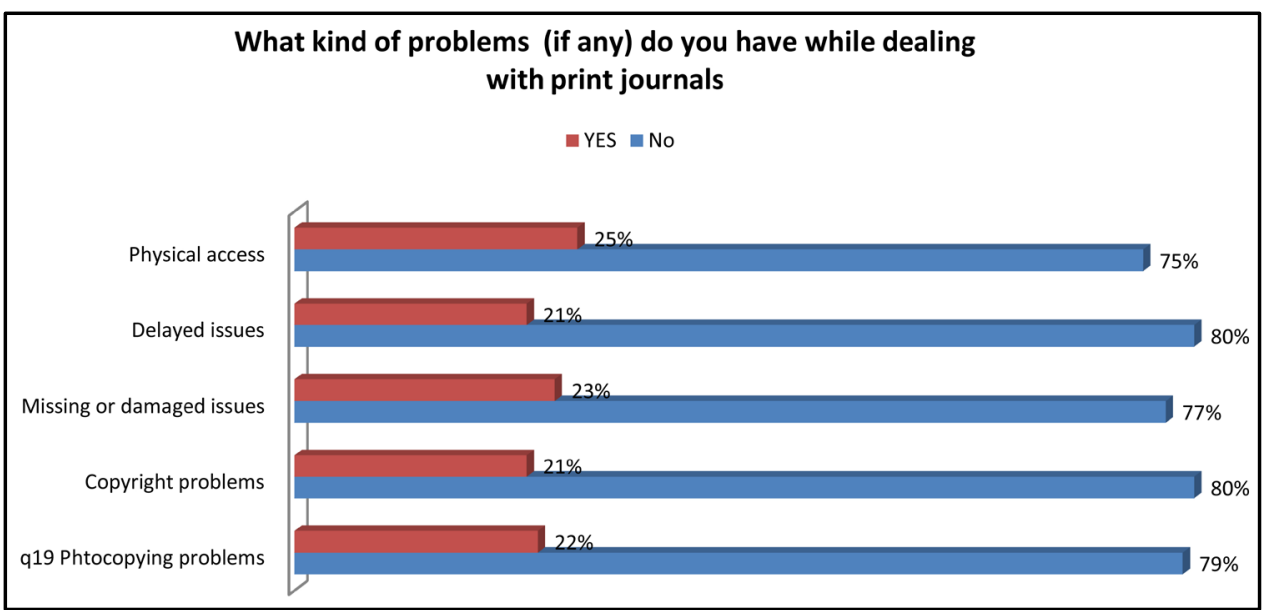

Figure 10. What kind of problems (if any) do you have while dealing with print journals? 
Although the above mentioned high preference found, most respondents (69\%) are still not convinced that print versions should be discarded or cancelled if they are duplicated electronically.

As electronic journals usage has increased, users face some problems like searching, accessing, saving and printing. On the other side there are some problems mentioned related to print journals like "physical access", "delayed issues" and "missing or damaged issues".

\subsection{Recommendations}

Based on the above findings of this study, the authors suggest the following recommendations:

- Libraries should allocate most of their journals subscriptions budget for the electronic version of these journals.

- Libraries should not totally cancel print journals as around two thirds of participants are still not convinced that this should be done.

- Libraries should check and solve some electronic journals usage problems like "access problems" and "searching problems".

- Libraries should check and solve some print journals usage problems like "physical access", "delayed issues" and "missing issues".

By implementing the above, libraries will help advance the field of knowledge management while better serving their patrons.

\section{References}

Adegbore, A. M. (2011). University Faculty Use of Electronic Resources: A Review of the Recent Literature. PNLA Quarterly, 75, 65-75.

https://web.b.ebscohost.com/ehost/resultsadvanced?sid=b65a4cb1-44fa-4343-b9b8-4fd3ec29ec 92\%40sessionmgr 198\&vid=3\&hid $=102 \&$ bquery=University + Faculty + Use $+\% 22$ of $\% 22+$ Electro

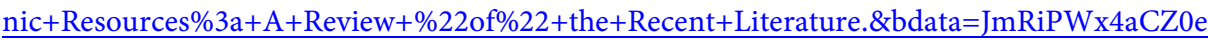
XBlPTEmc210ZT1laG9zdC1saXZlJnNjb3BlPXNpdGU\%3d

Aggarwal, S., \& Bhalla, V. (2012). A Study of Teacher Educator's Preference of Print and Electronic Resources of Information. International Journal of Information Dissemination and Technology, 2, 86.

http://pi.summon.serialssolutions.com/search?s.q=From+print+to+electronic\%3A+An+analytic al+study+of+changing+preference+among+users+of+health+science+libraries+in+haryana\#!/ search?ho=t\&l=en\&q=A\%20study\%20of\%20teacher\%20educator's\%20preference $\% 20$ of $\% 20$ pri nt\%20and\%20electronic\%20resources\%20of\%20information

Angrosh, M. A. (2005). Electronic and Print Journals: A Value Chain Analysis. Annals of Library \& Information Studies, 52, 56-64.

https://web.b.ebscohost.com/ehost/detail/detail?vid=5\&sid=b65a4cb1-44fa-4343-b9b8-4fd3ec2 9ec92\%40sessionmgr198\&hid=102\&bdata=JnNpdGU9ZWhvc3QtbGl2ZSZzY29wZT1zaXRl\#A $\mathrm{N}=23724389 \& \mathrm{db}=\mathrm{lxh}$

Cooper, M. M. (2007). The Importance of Gathering Print and Electronic Journal Use Data: Getting a Clear Picture. Serials Review, 33, 172-174.

https://web.b.ebscohost.com/ehost/detail/detail?vid=3\&sid=815d2f95-256a-42ed-bbfe-e7b3503ca cab\%40sessionmgr115\&hid=102\&bdata=JnNpdGU9ZWhvc3QtbGl2ZSZzY29wZT1zaXRl\#AN 
$=26336191 \& \mathrm{db}=1 \mathrm{xh}$

https://doi.org/10.1080/00987913.2007.10765118

Dastforoush, M., \& Venkatesha, V. V. (2011). Dependency on Electronic and Print Journals: A Case Study. SRELS Journal of Information Management, 48, 441-448.

https://web.b.ebscohost.com/ehost/detail/detail?vid=5\&sid=815d2f95-256a-42ed-bbfe-e7b3503ca cab\%40sessionmgr115\&hid=102\&bdata=JnNpdGU9ZWhvc3QtbGl2ZSZzY29wZT1zaXRl\#AN $=66930196 \& \mathrm{db}=\mathrm{lxh}$

Fortini, T. (2007). Going Online: Academic Libraries and the Move from Print to Electronic Journals. Library Student Journal, 2, 3-11.

https://web.b.ebscohost.com/ehost/detail/detail?vid=7\&sid=815d2f95-256a-42ed-bbfe-e7b3503ca cab\%40sessionmgr115\&hid=102\&bdata=JnNpdGU9ZWhvc3QtbGl2ZSZzY29wZT1zaXRl\#AN $=30006230 \& \mathrm{db}=1 \mathrm{xh}$

Juma, I. W., Wamukoya, J., \& Wekullo, C. (2014). The Role of Digital Libraries in Bridging the Knowledge Gap in Africa. Mousaion, 32, 64-83.

https://web.a.ebscohost.com/ehost/resultsadvanced?sid=29b6e35e-c5bb-4d93-b0f5-940920e3c7 $75 \% 40$ sessionmgr4006\&vid=2\&hid $=4112$ \&bquery $=\mathrm{XX}+\% 22$ bridging $\% 22 \% 5 \mathrm{~b} 100 \% 5 \mathrm{~d}+\mathrm{AND}+($ $\mathrm{XX}+\% 22 \mathrm{gap} \% 22 \% 5 \mathrm{~b} 79 \% 5 \mathrm{~d}+\mathrm{OR}+\mathrm{XX}+\% 22 \mathrm{africa} \% 22 \% 5 \mathrm{~b} 67 \% 5 \mathrm{~d}+\mathrm{OR}+\mathrm{XX}+\% 22$ digital $\% 22 \% 5 \mathrm{~b}$ $53 \% 5 \mathrm{~d}+\mathrm{OR}+\mathrm{XX}+\% 22 \mathrm{knowledge} \% 22 \% 5 \mathrm{~b} 53 \% 5 \mathrm{~d}+\mathrm{OR}+\mathrm{XX}+\% 22$ role $\% 22 \% 5 \mathrm{~b} 50 \% 5 \mathrm{~d}+\mathrm{OR}+\mathrm{XX}+$ \%22libraries\%22\%5b38\%5d)\&bdata=JmRiPWx4aCZ0eXBlPTEmc210ZT1laG9zdC1saXZlJnNjb 3BlPXNpdGU\%3d

Kumar, A., \& Gupta, D. K. (2013). From Print to Electronic: An Analytical Study of Changing Preference among Users of Health Science Libraries in Haryana, Chandigarh and Delhi. International Journal of Information Dissemination and Technology, 3, 76.

http://pi.summon.serialssolutions.com/search?s.q=From+print+to+electronic\%3A+An+analytic al+study+of+changing+preference+among+users+of+health+science+libraries+in+haryana\#!/ search?ho=t\&l=en\&q=From $\% 20$ print $\% 20$ to $\% 20$ electronic: $\% 20 \mathrm{An} \% 20$ analytical\%20study $\% 20$ of $\% 20$ changing $\% 20$ preference $\% 20$ among $\% 20$ users $\% 20$ of $\% 20$ health $\% 20$ science $\% 20$ libraries $\% 2$ 0in\%20haryana

Kumar, S., \& Grover, V. K. (2007). Electronic Journals: Impact on Scholarly Communication, User and Library. Library Herald, 45, 325-336.

http://www.indianjournals.com/ijor.aspx?target=ijor:lh\&volume $=45 \&$ issue $=4 \&$ article $=002$

Mazur, G. R. (2008). The Viability of Learning Journals as an Instructional Methodology for Adult Learners (Order No. 3324665). Available from ProQuest Dissertations \& Theses Full Text: The Humanities and Social Sciences Collection (230696010). http://search.proquest.com/docview/230696010?accountid=28396 http://search.proquest.com/docview/230696010/abstract/CA1EE889AD9D4C15PQ/6?accounti $\mathrm{d}=28396$

McClamroch, J. (2011). The Transition from Print to Electronic Journals: A Study of College and University Libraries in Indiana. Evidence Based Library \& Information Practice, 6, 40-52. https://web.a.ebscohost.com/ehost/detail/detail?vid=3\&sid=2b4f23ee-3efd-45b7-998e-5b1a40c 0028b\%40sessionmgr4007\&hid=4109\&bdata=JnNpdGU9ZWhvc3QtbGl2ZSZzY29wZT1zaXRl \#AN=67095780\&db=lxh https://doi.org/10.18438/B8561R

McMullen, A. (2014). Comparison of Usage Data of a Print Journal Title versus Electronic Counterpart. Bottom Line: Managing Library Finances, 27, 126-128.

http://pi.summon.serialssolutions.com/search?s.q=From+print+to+electronic\%3A+An+analytic al+study+of+changing+preference+among+users+of+health+science+libraries+in+haryana\#!/ search?ho=t\&l=en\&q=Comparison $\% 20$ of $\% 20$ usage $\% 20$ data $\% 20$ of $\% 20 \mathrm{a} \% 20$ print $\% 20$ journal $\%$ 20title\%20versus\%20electronic\%20counterpart.\%20Bottom\%20Line 
https://doi.org/10.1108/BL-10-2014-0025

Profera, E., \& Stamison, C. M. (2010). An Agent's Perspective on Issues and Best Practices When Shifting from Print to Electronic Resources. Serials Review, 36, 3-9.

https://web.a.ebscohost.com/ehost/resultsadvanced?sid=0f8b1c9e-1f7e-4814-8fc4-79cb66221ea $2 \% 40$ sessionmgr4010\&vid $=6 \&$ hid $=4204 \&$ bquery $=$ demand + for + electronic + content $+\% 22$ is $\% 22$ +rising+within+the+information+community\&bdata=JmRiPWx4aCZ0eXBlPTEmc210ZT1laG 9zdC1saXZlJnNjb3BlPXNpdGU\%3d https://doi.org/10.1016/j.serrev.2009.12.003

Rupp-Serrano, K., \& Robbins, S. (2013). Information-Seeking Habits of Education Faculty. College \& Research Libraries, 74, 131-141. https://doi.org/10.5860/crl-322

https://web.a.ebscohost.com/ehost/detail/detail?vid=12\&sid=4d738b3a-123c-47d2-825e-194b1 cb93ce2\%40sessionmgr4006\&hid $=4204 \&$ bdata $=$ InNpdGU9ZWhvc3QtbGl2ZSZzY29wZT1zaX $\mathrm{Rl} \# \mathrm{AN}=86038605 \& \mathrm{db}=\mathrm{lxh}$

Sathe, N. A., Grady, J. L., \& Giuse, N. B. (2002). Print versus Electronic Journals: A Preliminary Investigation into the Effect of Journal Format on Research Processes. Journal of the Medical Library Association, 90, 235-244.

https://web.b.ebscohost.com/ehost/detail/detail?vid=17\&sid=815d2f95-256a-42ed-bbfe-e7b350 3cacab\%40sessionmgr115\&hid=102\&bdata=JnNpdGU9ZWhvc3QtbGl2ZSZzY29wZT1zaXRl\# $\mathrm{AN}=\mathrm{ISTA} 3702287 \& \mathrm{db}=\mathrm{lxh}$

Schloegl, C., \& Gorraiz, J. (2011). Global Usage versus Global Citation Metrics: The Case of Pharmacology Journals. Journal of the American Society for Information Science and Technology, 62, 161-170. https://doi.org/10.1002/asi.21420

http://pi.summon.serialssolutions.com/document/show?id=FETCHMERGED-LOGICAL-c236 0-4d8ccb812ee4151afddbd2b3eb4f6616d201e908647972f3b19731c55ae447c52\&s.q=Global+usa ge+versus+global+citation+metrics $\% 3 \mathrm{~A}+\mathrm{The}+$ case + of + pharmacology+journals

Stoop, J., Kreutzer, P., \& Kircz, J. G. (2013). Reading and Learning from Screens versus Print: A Study in Changing Habits, Part 2: Comparing Different Text Structures on Paper and on Screen. New Library World, 114, 371-383. https://doi.org/10.1108/NLW-04-2013-0034 http://pi.summon.serialssolutions.com/search?s.q=From+print+to+electronic\%3A+An+analytic al+study+of+changing+preference+among+users+of+health+science+libraries+in+haryana\#!/ search?ho=t\&l=en\&q=Reading\%20and\%20learning\%20from\%20screens\%20versus\%20print:\% 20a\%20study\%20in\%20changing\%20habit

Tenopir, C. (2002). Electronic or Print: Are Scholarly Journals Still Important? Serials, 15, 111115. https://doi.org/10.1629/15111

https://web.b.ebscohost.com/ehost/detail/detail?vid=29\&sid=815d2f95-256a-42ed-bbfe-e7b350 3cacab\%40sessionmgr115\&hid=102\&bdata=JnNpdGU9ZWhvc3QtbGl2ZSZzY29wZT1zaXRl\# AN=ISTA3704041\&db=lxh

Tobia, R. C., \& Hunnicutt, S. C. (2008). Print Journals in the Electronic Library: What Is Happening to Them? Journal of Electronic Resources in Medical Libraries, 5, 161-170.

https://web.b.ebscohost.com/ehost/detail/detail?vid=27\&sid=815d2f95-256a-42ed-bbfe-e7b350 3cacab\%40sessionmgr115\&hid=102\&bdata=JnNpdGU9ZWhvc3QtbGl2ZSZzY29wZT1zaXRl\# $\underline{\mathrm{AN}=33722060 \& \mathrm{db}=\mathrm{lxh}}$ https://doi.org/10.1080/15424060802064360 
Submit or recommend next manuscript to SCIRP and we will provide best service for you:

Accepting pre-submission inquiries through Email, Facebook, LinkedIn, Twitter, etc. A wide selection of journals (inclusive of 9 subjects, more than 200 journals)

Providing 24-hour high-quality service

User-friendly online submission system

Fair and swift peer-review system

Efficient typesetting and proofreading procedure

Display of the result of downloads and visits, as well as the number of cited articles

Maximum dissemination of your research work

Submit your manuscript at: http://papersubmission.scirp.org/

Orcontact ajc@scirp.org 